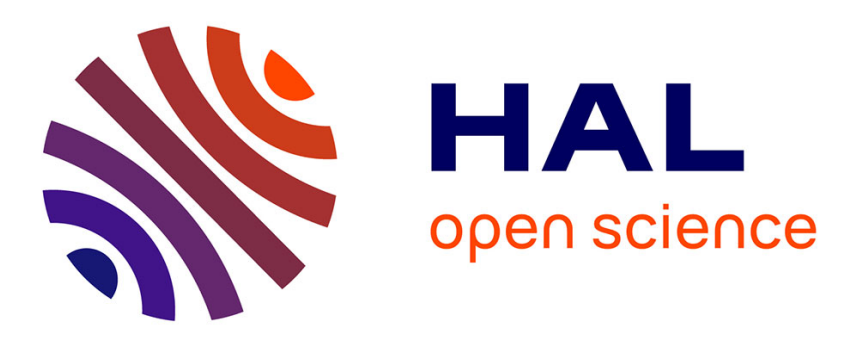

\title{
Copper(II)-dipicolinate-mediated clickable azide-alkyne cycloaddition in water as solvent
}

Lahoucine Bahsis, Hicham Ben El Ayouchia, Hafid Anane, Smail Triki, Miguel Julve, Salah-Eddine Stiriba

\section{- To cite this version:}

Lahoucine Bahsis, Hicham Ben El Ayouchia, Hafid Anane, Smail Triki, Miguel Julve, et al.. Copper(II)-dipicolinate-mediated clickable azide-alkyne cycloaddition in water as solvent. Journal of Coordination Chemistry, In press, 10.1080/00958972.2018.1435870 . hal-01701698

\section{HAL Id: hal-01701698 \\ https://hal.univ-brest.fr/hal-01701698}

Submitted on 7 Feb 2018

HAL is a multi-disciplinary open access archive for the deposit and dissemination of scientific research documents, whether they are published or not. The documents may come from teaching and research institutions in France or abroad, or from public or private research centers.
L'archive ouverte pluridisciplinaire HAL, est destinée au dépôt et à la diffusion de documents scientifiques de niveau recherche, publiés ou non, émanant des établissements d'enseignement et de recherche français ou étrangers, des laboratoires publics ou privés. 
Journal of Coordination Chemistry (Revised Version)

A contribution dedicated to our friend Prof. J. Faus in recognition of his outstanding career

\title{
Copper(II)-dipicolinate-mediated clickable azide-alkyne cycloaddition in water as solvent
}

\author{
LAHOUCINE BAHSIS $^{\mathrm{a}}$, HICHAM BEN EL AYOUCHIA ${ }^{\mathrm{a}}$, HAFID ANANE ${ }^{\mathrm{a}}$, SMAIL \\ TRIKI $^{\text {b,* }}$, MIGUEL JULVE ${ }^{c}$, AND SALAH-EDDINE STIRIBA ${ }^{\mathrm{a}, \mathrm{c}, *}$
}

${ }^{a}$ Laboratoire de Chimie Analytique et Moléculaire, LCAM, Faculté Polydisciplinaire de Safi, Université Cadi Ayyad, Safi, Morocco

${ }^{b}$ Laboratoire de Chimie, Electrochimie Moléculaires et Chimie Analytique, UMR CNRS 6521, Université de Brest, BP 809, 29238 Brest, France

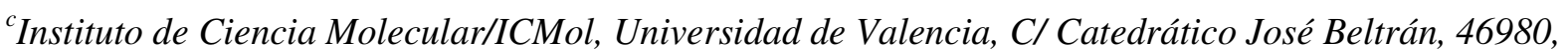
Valencia, Spain

* Corresponding authors: Tel/Fax: +34 963544445 / +34 963543273

E-mail: stiriba@uv.es, smail.triki@univ-brest.fr 


\begin{abstract}
Copper(II)-dipicolinate complex $\left[\mathrm{Cu}{ }^{\mathrm{II}} \mathrm{L}\left(\mathrm{H}_{2} \mathrm{O}\right)_{2}\right](\mathbf{1}),\left(\mathrm{H}_{2} \mathrm{~L}=\right.$ dipicolinic acid $\left(\mathrm{H}_{2}\right.$ dipic)) was synthesized via oxidation reaction of copper(I) iodide and pyridine-2,6-dicarboxylic acid in water and acetonitrile in presence of glycine. Complex 1 was characterized by FT-IR and elemental analysis and its structure confirmed by single crystal X-ray analysis. This complex is an efficient precatalyst that mediates azide-alkyne cycloaddition reactions in water at room temperature either in the absence or presence of a reducing agent. Compound 1-mediated azide-alkyne cycloaddition affords alkyl/aryl substituted 1,2,3-triazole heterocycles in a regioselective manner and excellent yields under very mild reaction conditions matching the criteria of greener protocols.

Keywords: Dipicolinic acid; Copper; Homogenous catalysis; Click chemistry; Azide-alkyne cycloaddition; 1,2,3-Triazoles.
\end{abstract}




\section{Introduction}

Since its discovery by Huisgen, the azide-alkyne [3+2] cycloaddition reaction (AAC) has become a good strategy for the synthesis of 1,2,3-triazole heterocycles. The original noncatalyzed side of AAC reaction, known as Huisgen reaction, was characterized by slow rate and low selectivity due to the high reaction kinetic barrier [1-2]. Because of the high temperature used, the low yields and also the lack of selectivity, Sharpless and Meldal introduced the copper(I)-catalyzed azide-alkyne cycloaddition (CuAAC), that leads to the effective and regioselective formation of 1,2,3-triazoles by using catalytic copper species [35]. Since then, this transformation becomes the model reaction within the concept of "click chemistry" because it proceeds effectively under mild conditions with high regioselectivity and with less work-up. The CuAAC reaction has been widely applied in medicinal, biological, and materials chemistry [6-8]. Moreover, 1,2,3-triazole molecules have been used in industrial applications, such as corrosion retarding agents, dyes, chemical sensors and energetic materials [9-12].

Traditionally, the standard catalytic system of CuAAC consists of copper(II) salts with a reducing agent (such as sodium ascorbate) [4a]. Later, it was reported that copper(I) salts could be also used directly for this reaction, usually with stabilizing ligands [4b]. Recently, Kuang et al. discovered that under reducing agent free conditions, copper(II)-chelation undergoes much faster CuAAC. In fact, the in situ formation of the catalytically active copper(I) species in alcoholic media occurs by using chelating picolyl azide substrates [13]. The catalytic copper(I) species are generated by the reduction of copper(II) via either alcohol oxidation or alkyne homocoupling, or both, during an induction period [14].

In the last decade, the development of new ligands bearing nitrogen and oxygen atom-donors has attracted much recent attention in the fields of catalysis, organic synthesis and biologic activity, especially in terms of stabilization of the metal center involved in such applications 
[15]. Dipicolinic acid (hereafter noted as $\mathrm{H}_{2}$ dipic) which was discovered in 1936 is now applied as bacterial spores [16] and enzyme inhibitor [17]. It is characterized by its capability in serving as hydrogen bonding donor and acceptor [18] and its deprotonated anions (Hdipic and dipic $^{2-}$ ) are well suited to build different networks in the context of the coordination chemistry of metal-organic frameworks engineering, because of the presence of two carboxylate groups as substituents on 1,5 positions at the pyridyl ring. This arrangement of potential donor atoms provides several coordination modes as shown by the crystal structures of its metal complexes [19-23]. Metal(II)-dipicolinate complexes were mainly characterized by their antimicrobial activities [24-25]. Bearing this in mind, we herein report the synthesis and X-ray characterization of a new dipicolinate-containing copper(II) complex of formula $\left[\mathrm{Cu}^{\mathrm{II}} \mathrm{L}\left(\mathrm{H}_{2} \mathrm{O}\right)_{2}\right](\mathbf{1})$ [26], together with its application as a greener, efficient, precatalyst for the synthesis of 1,4-disubstituted 1,2,3-triazoles in water at room temperature. This protocol allows the synthesis of several 1,2,3-triazoles without need for an additional reducing agent. To the best of our knowledge, this is the first application of a given copper(II)-dipicolinate species as precatalyst in click chemistry.

\section{Experimental}

\subsection{Materials and methods}

Dipicolinic acid (pyridine-2,6-dicarboxylic acid) and copper(I) iodide were purchased from Sigma-Aldrich. All alkynes were commercially available and were used without further purification. Anhydrous $\mathrm{MgSO}_{4}$ was used to dry organic extracts and all volatiles were removed under reduced pressure. All reaction mixtures were monitored by TLC using commercial glass backed thin layer chromatography (TLC) plates (Merck Kieselgel 60 F254) and spots were visualized by UV light at $254 \mathrm{~nm}$. FT-IR $\left(4000-450 \mathrm{~cm}^{-1}\right)$ spectra were recorded on a FTIR spectrophotometer (FT-IR Nicolet 5700). ${ }^{1} \mathrm{H}$ NMR and ${ }^{13} \mathrm{C}$ NMR were 
carried out in $\mathrm{CDCl}_{3}$ solvents on a Bruker DRX-300 spectrometer. GC-MS spectra were performed with an Agilent 5973N mass spectrometer equipped with capillary columns (spli/splitless, pulsed split and pulsed splitless) at the SCSIE (Servicio Central de Soporte a la Investigación Experimental) of the University of Valencia. Melting points were determined in open capillaries using an Electro thermal 9100.

\subsection{Preparation of $[\mathrm{Cu}$}

Dipicolinic acid $(0.5 \mathrm{mmol}, 83.6 \mathrm{mg})$ was dissolved in glycine $(0.5 \mathrm{mmol}, 37.8 \mathrm{mg})$ and distilled water $(10 \mathrm{~mL})$ at $60{ }^{\circ} \mathrm{C}$. A solution of copper(I) iodide $(0.5 \mathrm{mmol}, 95 \mathrm{mg})$ in $8 \mathrm{~mL}$ of acetonitrile was added to the reaction mixture. The resulting solution was stirred for $0.5 \mathrm{~h}$ at $60{ }^{\circ} \mathrm{C}$ then kept at room temperature for two weeks to give blue blocks suitable for X-ray diffraction. They were collected by filtration, washed several times with distilled water and dried at room temperature. Yield: 80\%. IR (KBr/cm $\left.{ }^{-1}\right)$ : $3400(\mathrm{O}-\mathrm{H}), 2911(\mathrm{C}-\mathrm{H})$, 1686, 1647, $(\mathrm{C}=\mathrm{O}), 917,775,737,594,436$. Anal. Calcd for $\mathrm{C}_{14} \mathrm{H}_{14} \mathrm{Cu}_{2} \mathrm{~N}_{2} \mathrm{O}_{12}(1,529.35 \mathrm{~g} / \mathrm{mol}): \mathrm{C}, 31.77$; H, 2.67; N, 5.29. Found: C, 31.83; H, 2.75; N, 5.25\%.

\subsection{General procedure for the copper-catalyzed azide-alkyne cycloaddition}

A $25 \mathrm{~mL}$ round bottom flask was charged with 1 (5 mol \%), azide $(1.2 \mathrm{mmol})$, terminal alkyne $(1 \mathrm{mmol})$ and water $(2 \mathrm{~mL})$. The mixture was stirred at room temperature and the reaction progress monitored by TLC until the starting materials were consumed. The reaction mixture was then extracted with ethyl acetate $(3 \times 15 \mathrm{~mL})$ and the combined organic fractions were washed with a saturated $\mathrm{NaHCO}_{3}$ solution $(3 \times 10 \mathrm{~mL})$ and with brine $(20 \mathrm{~mL})$. After drying over $\mathrm{MgSO}_{4}$ the ethyl acetate was removed under reduced pressure and the resulting 1,2,3-triazoles were obtained without further purification. The structures of the 1,2,3-triazole

molecules were confirmed by NMR spectroscopy $\left({ }^{1} \mathrm{H},{ }^{13} \mathrm{C}\right.$ NMR $)$ and mass spectrometry. 


\subsection{Single crystal X-ray structure determination of $\left[\mathrm{Cu}{ }^{\mathrm{II}} \mathrm{L}\left(\mathrm{H}_{2} \mathrm{O}\right)_{2}\right]$ complex (1)}

Single crystal X-ray studies were performed at $293 \mathrm{~K}$ using an Oxford Diffraction Xcalibur 2 -CCD diffractometer fitted with a graphite monochromated $\operatorname{MoK} \alpha$ radiation $(\lambda=0.71073 \AA)$. A blue prismatic single crystal of $0.28 \times 0.16 \times 0.13 \mathrm{~mm} 3$ was used to collect the data. The crystal structure was solved by direct methods with the SHELXS program and refined on $F^{2}$ by weighted full matrix least-squares methods using the SHELXL program [27] All nonhydrogen atoms were refined anisotropically, while the hydrogen atoms of the dipicolinic anion, located in difference Fourier maps, were refined isotropically; the $\mathrm{H}$ atoms of the coordinated water molecule were not found. Crystallographic data and refinement details are depicted in Table 1S (Supp. Inf.) whereas selected bond lengths and angles are listed in Table 1.

\section{Results and discussion}

\subsection{Synthesis and characterization}

Copper(II)-dipicolinate complex $\left[\mathrm{Cu}^{\mathrm{II}} \mathrm{L}\left(\mathrm{H}_{2} \mathrm{O}\right)_{2}\right]$ (1) was synthesized via oxidation reaction of copper(I) iodide and dipicolinic acid in water and acetonitrile in the presence of glycine (Scheme 1). Glycine was used to form water soluble copper(II) systems from the insoluble cuprous(I) ones [28], that react readily directly with the dipicolinic acid without need to form the corresponding salt of the diacid as previously reported [26]. The final copper(II)dipicolinate complex was obtained after slow evaporation, as blue single crystals in a good yield (80\%) equal the one reported by reacting dipicolinic acid and copper(II) sulfate in water and acetonitrile [29]. Compound $\mathbf{1}$ which is soluble in acetone and ethanol and slightly soluble in water was already prepared by the reaction of the disodium salt of dipicolinic acid and copper(II) sulfate in a 1:1 molar ratio in water under boiling conditions and crystallization 
by cooling at low temperature [26]. It was characterized by FT-IR spectroscopy, elemental analysis and its structure elucidated by single crystal X-ray crystallography.

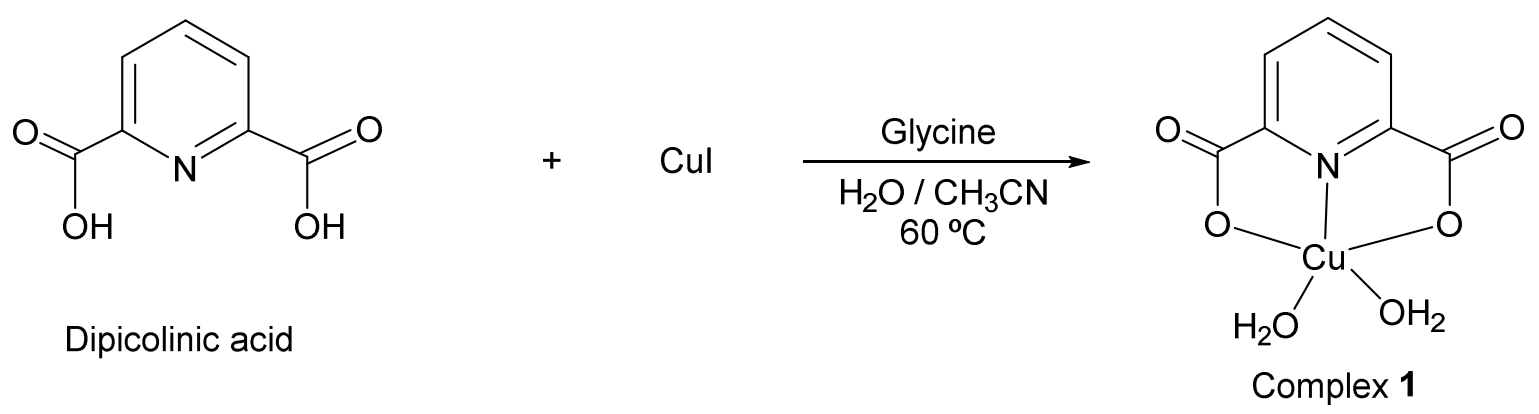

Scheme 1. Preparative route of complex 1.

The FT-IR spectra of the dipicolinic acid $\left(\mathrm{H}_{2} \mathrm{~L}\right)$ and $\mathbf{1}$ are shown in Figure 1. The FT-IR spectrum of complex 1 shows a strong band centered at $3400 \mathrm{~cm}^{-1}$ identical to the one previously reported and which corresponds to both asymmetric and symmetric O-H stretching vibrations, confirming then the presence of water in the complex [26]. The coordination of water molecules to the copper(II) ion in $\mathbf{1}$ is evidenced by the rocking and wagging peaks observed at 917, 775 and $737 \mathrm{~cm}^{-1}$ of the hydroxyl groups [29]. In addition, the absorption bands near 1686 and $1647 \mathrm{~cm}^{-1}$ which are attributed to the asymmetric stretching vibration of carboxylate groups indicate that the band for the stretching vibrations of the $\mathrm{C}=\mathrm{O}$ bonds of non-ionized carboxyl groups used to be in the range $1700-1750 \mathrm{~cm}^{-1}$ is not present in $\mathbf{1}$. The ring wagging vibration of the pyridyl group is also observed at $685 \mathrm{~cm}^{-1}$ for $\mathbf{1}$. The presence of a weak peak at $594 \mathrm{~cm}^{-1}$ may be assigned to the stretching vibration of the $\mathrm{Cu}-\mathrm{N}$ bond [30] and that observed at $436 \mathrm{~cm}^{-1}$ is due to the stretching vibration of the $\mathrm{Cu}-\mathrm{O}$ bond [31]. 


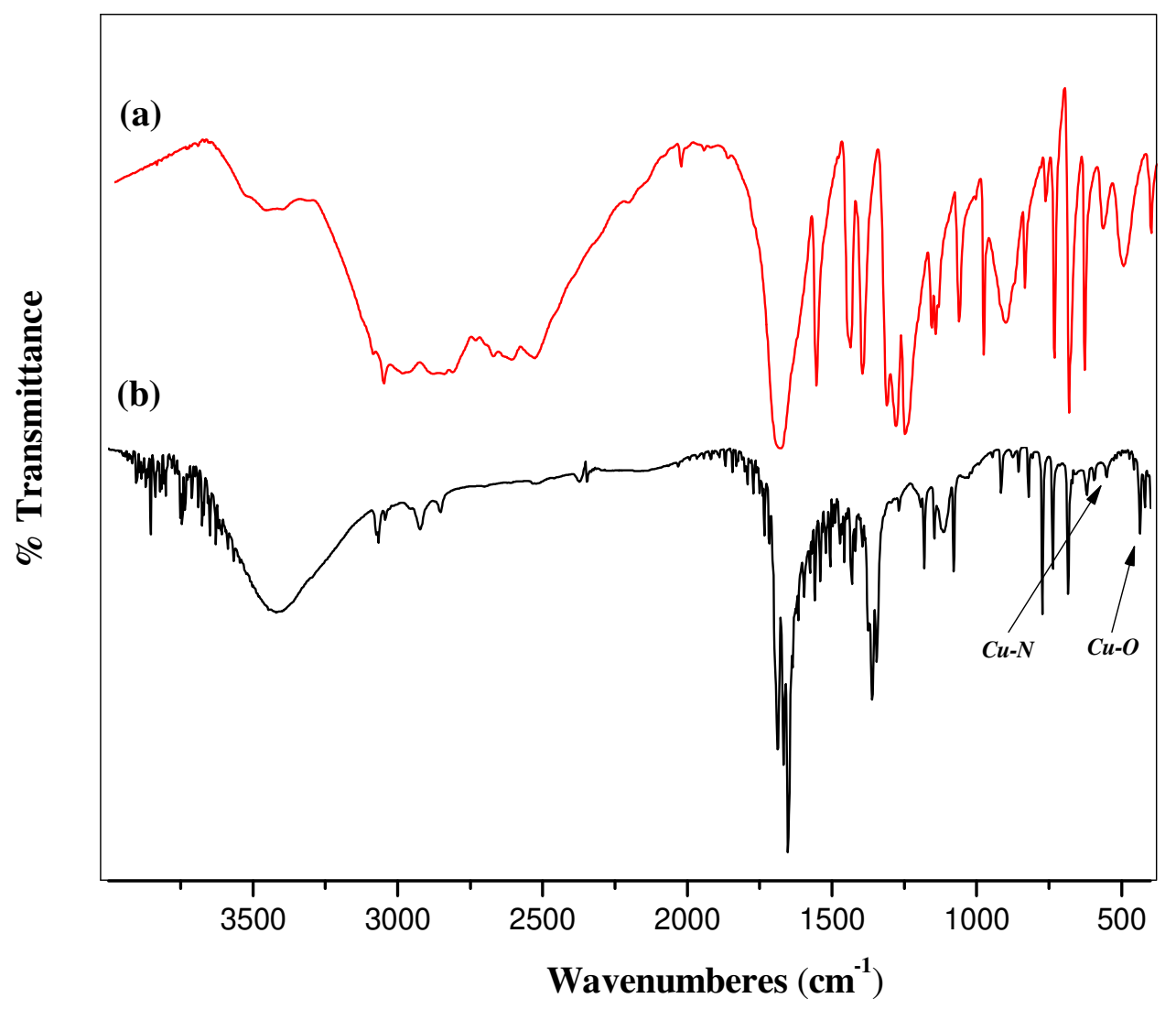

Figure 1. FT-IR spectra of (a) the dipicolinic acid and (b) complex 1.

To further characterize complex $\mathbf{1}$ its solid state structure that was already reported, was elucidated by single X-ray analysis [26]. Indeed, complex 1, isolated by us corresponds to the triclinic isomer featured by a $\mathrm{Cu}(\mathrm{II})$ ion having a distorted square pyramidal $\mathrm{CuNO}_{4}$ chromophore with an almost planar $\mathrm{CuN} 1 \mathrm{O} 1 \mathrm{O} 2 \mathrm{O} 3$ unit the value of the largest deviation from the mean plane being $0.21 \AA$. The value of the trigonality parameter $\tau$ is 0.052 [32]. The values of the $\mathrm{Cu}-\mathrm{O}$ and the $\mathrm{Cu}-\mathrm{N}$ bond distances in the basal plane [2.022(4), 2.016(5), 1.988(4) and 1.921(5) ^)] for $\mathrm{Cu} 1-\mathrm{O} 1, \mathrm{Cu} 1-\mathrm{O} 2, \mathrm{Cu} 1-\mathrm{O} 3$ and $\mathrm{Cu} 1-\mathrm{N} 1$, respectively are significantly shorter than the apical interaction [Cu1-O4 (2.169(5) $\AA$ )]. The main source of distortion respect to the ideal square pyramid is due to the two fused five-membered chelate rings whoseangles subtended at the copper (II) ion by the tridentate L are 80.9(2) (N1-Cu1$\mathrm{O} 1)$ and $80.2(2)^{\circ}$ for $(\mathrm{N} 1-\mathrm{Cu} 1-\mathrm{O} 2)$. 


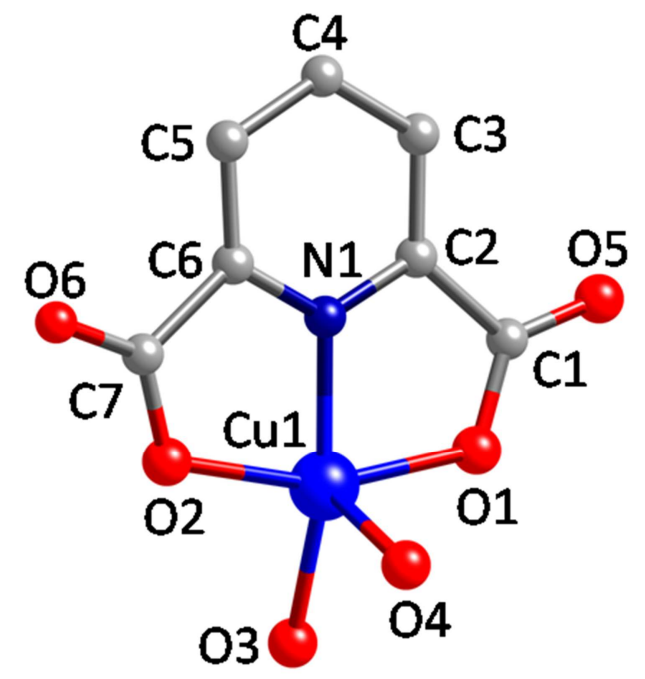

Figure 2. Perspective view of the structure of $\mathbf{1}$. The hydrogen atoms have been omitted for clarity [26].

A relevant structural aspect concerns the environment of the copper (II) ion because of the weak axial Cu1-O6a interaction [Cu...O6a: 3.175(4) $\AA$; symmetry code: $(a)=1,0,0]$. This feature allows us to consider the surrounding of the copper centre as an elongated octahedron. This interaction leads to a supramolecular chain which runs along the crystallographic a axis.

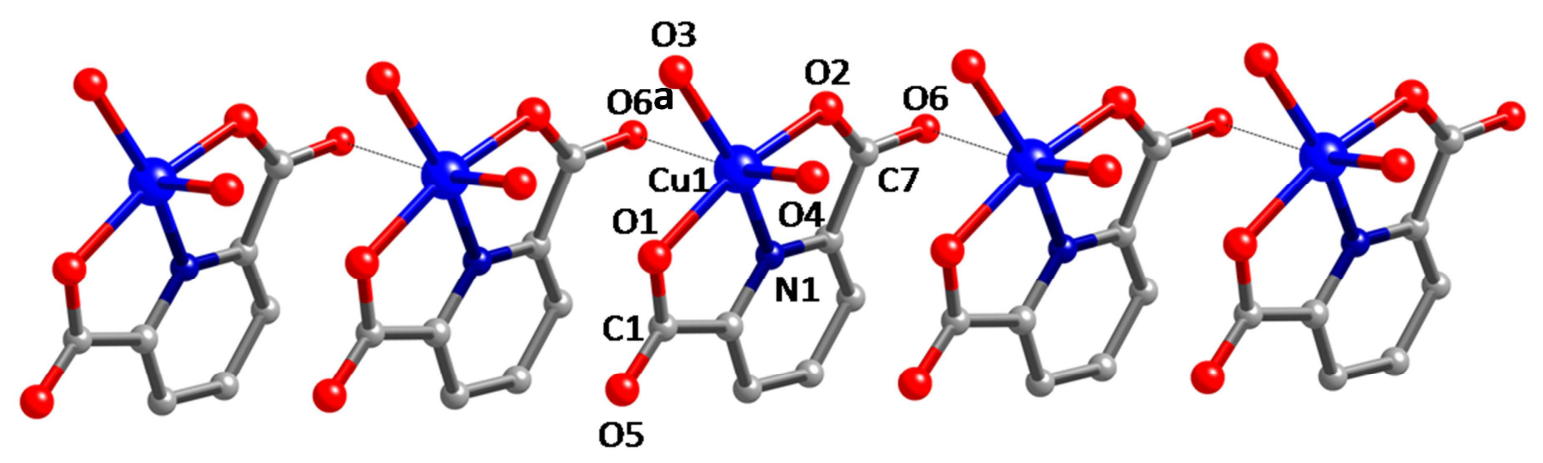

Figure 3. View of the supramolecular chain of 1 growing along the [100] direction. 
Table 1. Selected bond lengths $(\AA)$ and angles $\left(^{\circ}\right)$ of $\mathbf{1}$

\begin{tabular}{rr}
$\mathrm{Cu} 1-\mathrm{N} 1$ & $1.921(5)$ \\
$\mathrm{Cu} 1-\mathrm{O} 1$ & $2.022(4)$ \\
$\mathrm{Cu} 1-\mathrm{O} 2$ & $2.016(5)$ \\
$\mathrm{Cu} 1-\mathrm{O} 4$ & $1.988(4)$ \\
O1-Cu1-O4 & $2.169(5)$ \\
O2-Cu1-O1 & $96.1(2)$ \\
O2-Cu1-O4 & $160.7(2)$ \\
O3-Cu1-O1 & $94.0(2)$ \\
O3-Cu1-O2 & $97.0(2)$ \\
O3-Cu1-O4 & $98.8(2)$ \\
N1-Cu1-O1 & $93.0(2)$ \\
N1-Cu1-O2 & $80.9(2)$ \\
N1-Cu1-O3 & $80.2(2)$ \\
N1-Cu1-O4 & $157.6(2)$ \\
\hline
\end{tabular}

\subsection{Copper-catalyzed azide-alkyne cycloaddition}

The catalytic performance of the prepared $\mathrm{Cu}(\mathrm{II})$-dipicolinate complex $\mathbf{1}$ was examined in the cycloaddition between phenylacetylene and benzyl azide, which was chosen as a model reaction in order to optimize the suitable catalytic conditions (Table 2). For this purpose, various solvents were screened pointing to water as a suitable solvent for such a cycloaddition reaction. The reaction gave poor to moderate yields in hexane, acetonitrile, ethanol and even in an ethanol/water mixture employed as solvents with 10 mol\% of 1 (see entries 1-4, Table 2). When using 5-15 mol\% of precatalyst 1 in water as solvent, excellent yields of the corresponding 1,2,3-triazole were obtained working at room temperature (entries 5-7, Table 2). Even a further decrease of the precatalyst loading to $3 \mathrm{~mol} \%$ led to a good yield (entry 8 , Table 2). In the light of these results, the use of $5 \mathrm{~mol} \%$ of $\mathbf{1}$ in water at room 
temperature appears to be the suitable catalytic conditions for complex 1-mediated azidealkyne cycloaddition reactions.

Table 2. Optimization of the catalytic conditions for the complex 1-mediated benzyl azidephenylacetylene cycloaddition reaction

\begin{tabular}{cccc} 
& & & \\
\hline & & & \\
\hline Entry & $\begin{array}{c}\text { Amount of catalyst } \\
(\mathbf{m o l} \%)\end{array}$ & Solvent & Yield (\%) $)^{\mathbf{b}}$ \\
\hline 1 & 10 & Hexane & 48 \\
2 & 10 & Acetonitrile & 55 \\
3 & 10 & Ethanol & 60 \\
4 & 10 & Ethanol/Water & 70 \\
5 & 15 & Water & 97 \\
6 & 10 & Water & 95 \\
7 & 5 & Water & $\mathbf{9 0}$ \\
8 & 3 & Water & 70 \\
\hline
\end{tabular}

${ }^{\mathrm{a}}$ Reaction conditions: $0.313 \mathrm{mmol}$ phenylacetylene, $0.376 \mathrm{mmol}$ benzyl azide, $24 \mathrm{~h}, 2$ $\mathrm{mL}$ of solvent and r.t. ${ }^{\mathrm{b}}$ Isolated yields.

After optimizing the conditions of the complex 1-mediated phenylacetylene-benzyl azide cycloaddition, the catalytic scope of this complex was expanded to the cycloaddition of various azide and alkyne derivatives (Table 3). A variety of alkynes was reacted with benzyl azide using $5 \mathrm{~mol} \%$ of $\mathbf{1}$ in water at room temperature (entries 1-6, Table 3). The substrates containing electron-withdrawing groups appear to be less reactive than those containing electron-neutral and electron-donating groups (entries 3 and 6, Table 3), and as most of the reactions, they were completed within $24 \mathrm{~h}$ affording high yields of the corresponding 1,2,3triazoles. In addition, a variety of azides was in turn reacted with phenyl acetylene resulting in 
the formation of the corresponding 1,2,3-triazoles in high yields too (entries 7-9, Table 3). The corresponding 1,2,3-triazoles were obtained in excellent yields in all catalytic experiments and most importantly, the final products did not require any further purification by conventional methods. The products were fully characterized by their melting point and also by ${ }^{1} \mathrm{H}$ NMR, ${ }^{13} \mathrm{C}$ NMR spectroscopy and mass spectrometry (Supporting information).

Table 3. Cycloaddition of azides with terminal alkynes in presence of $\mathbf{1}$
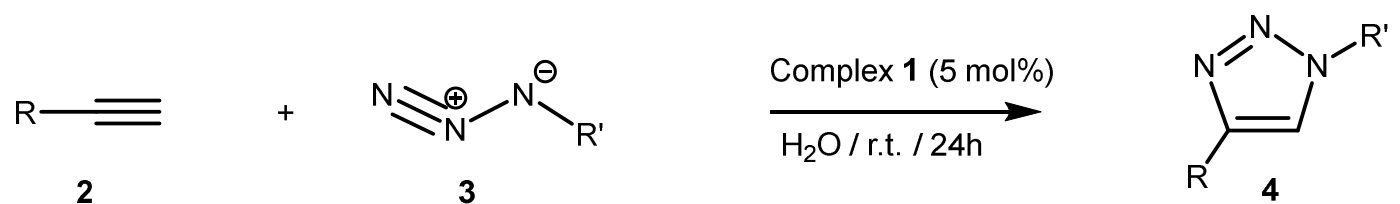

1,4-disubstitued 1,2,3-triazole

Entry


${ }^{\text {a }}$ Reaction conditions: $0.313 \mathrm{mmol}$ alkyne, $0.376 \mathrm{mmol}$ azide, $24 \mathrm{~h}, 2 \mathrm{~mL}$ water and r.t. ${ }^{\mathrm{b}}$ Isolated yields.

It appears that the process by which catalytic active copper(I) species have been generated to catalyze azide-alkyne cycloaddition in water for such a long reaction time of $24 \mathrm{~h}$ occurs via alkyne homocoupling. In fact, the presence of a reducing agent such as ascorbic acid or hydrazine decreases the cycloaddition reaction time between benzyl azide and phenylacetylene, being achieved in 45-50 min with very high yields of the 1,4-disubstitued 1,2,3-triazole (entries 1-2, Table 4). It is noteworthy that the corresponding 1,4-disubstituted1,2,3-triazole was obtained in high yield after 10 min using ascorbic acid as reducing agent under ultrasound irradiation conditions (entry 3, Table 4). However, under the same ultrasound conditions, clicking both azide and alkyne substrates in presence of $\mathbf{1}$ without reductant get failed (entry 4 , Table 4$)$.

Table 4. Effect of the method for the syntheses of 1,4-disubstituted-1,2,3-triazole catalyzed by 1

\begin{tabular}{ccccc}
\hline & & & & Complex 1 \\
\hline Entry & Additives & Time & Stirring method & Yield (\%) \\
\hline 1 & Ascorbic acid & $50 \mathrm{~min}$ & Magnetic stirring & 96 \\
2 & Hydrazine & $45 \mathrm{~min}$ & Magnetic stirring & 95 \\
3 & Ascorbic acid & $10 \mathrm{~min}$ & Ultrasonic & 85 \\
4 & - & $30 \mathrm{~min}$ & Ultrasonic & Traces \\
\hline
\end{tabular}


By analogy with earlier results reported by Kuang [14,33], the plausible mechanistic pathways for the synthesis of 1,4-disubstituted 1,2,3-triazoles in the presence of $\mathbf{1}$ is shown in Scheme 3. In the first step, the catalytic copper(I) species emerges via reducing complex $\mathbf{1}$ by terminal alkyne via oxidative alkyne homocoupling reaction. Then, the catalytically active copper(I) species formed in situ coordinates to the terminal alkyne to form the acetylidecopper intermediate. In the second step, the copper-acetylide reacts with the azide derivative and a six-membered copper-metallated triazolide results through the rearrangement of the intermediate. Finally, the intermediate copper triazoloid captures one proton to afford the final 1,2,3-triazole product (Scheme 2).
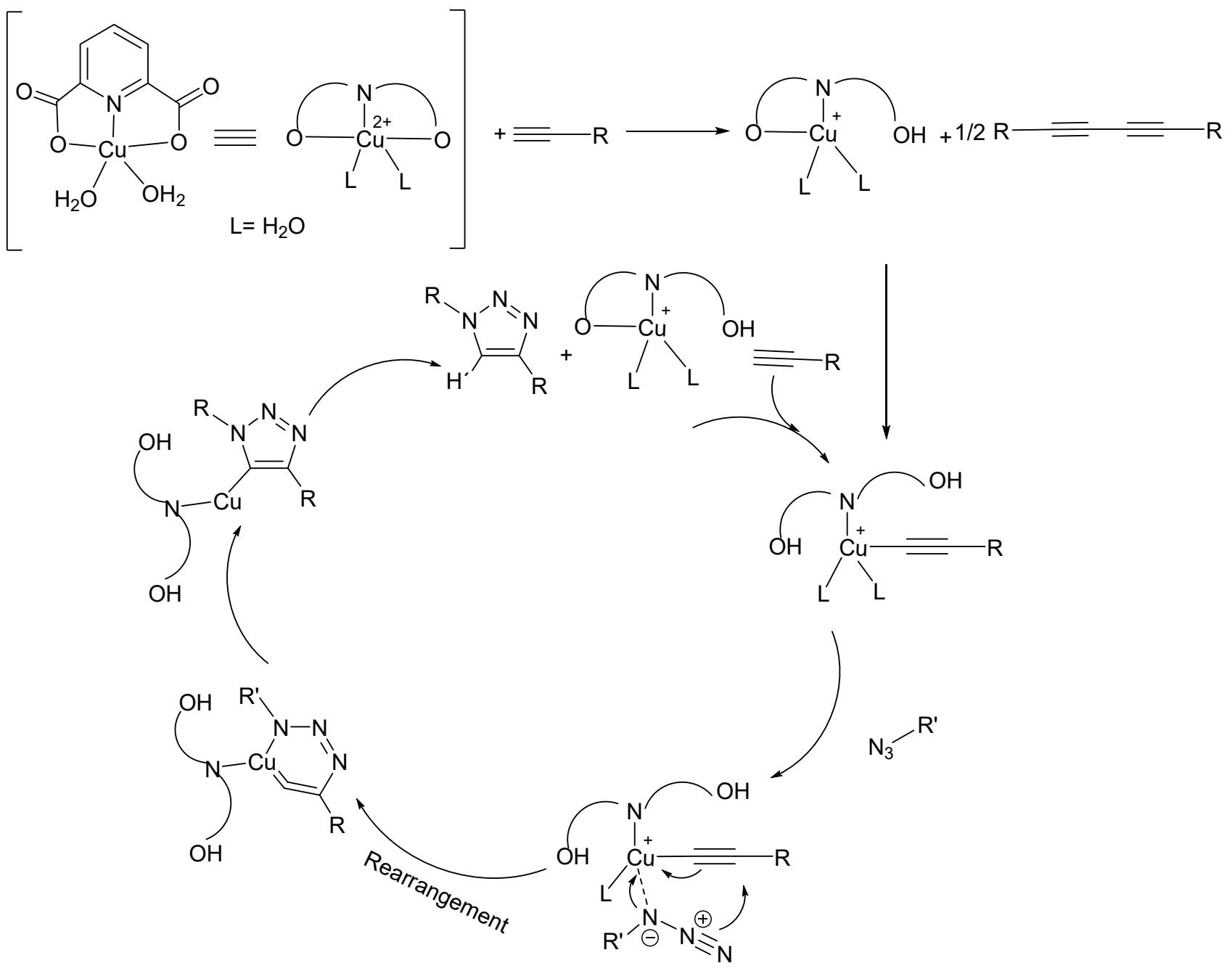

Scheme 2. The proposed mechanism for the formation of 1,2,3-triazole mediated by $\mathbf{1}$. 
In order to show the utility and potential of the complex 1-mediated azide-alkyne cycloaddition, we compared its catalytic reactivity versus other copper(II) complexes (Table 5). It is clear that the presence of a reducing agent and the performance of the cycloaddition reaction at high-temperature and under inert atmosphere are prerequisites for some catalytic systems to be operating. In contrast, complex 1-mediated azide-alkyne cycloaddition reaction occurs in an effective manner, working at air and at room temperature in water, followed by an easy work-up protocol for the final separation of 1,2,3-triazole product.

Table 5. A comparison study of complex 1 with the previous reported precatalysts in the cycloaddition of benzyl azide and phenylacetylene

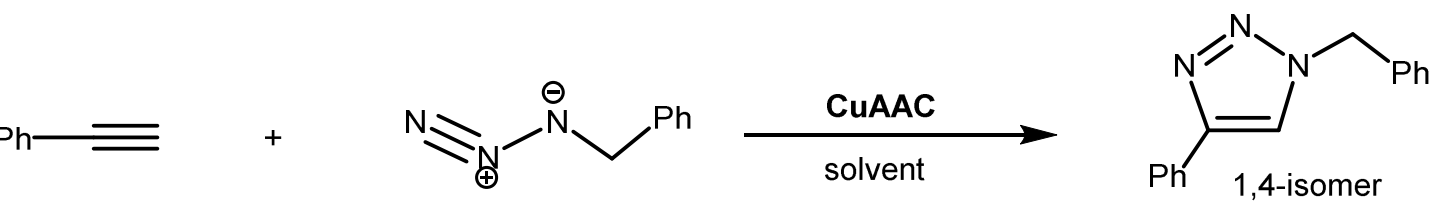

\begin{tabular}{|c|c|c|c|c|c|c|}
\hline Entry & Catalyst & Additives & Conditions & $\begin{array}{c}\text { Time } \\
\text { (h) }\end{array}$ & $\begin{array}{c}\text { Yield } \\
(\%)\end{array}$ & Ref. \\
\hline 1 & $\mathrm{Cu}\left(\mathrm{NO}_{3}\right)_{2} \cdot 3 \mathrm{H}_{2} \mathrm{O}$ & - & $\mathrm{H}_{2} \mathrm{O} /$ r.t. & 20 & 13 & [34] \\
\hline 2 & {$\left[\left(\mathrm{C}_{2} \mathrm{H}_{5}\right)_{4} \mathrm{~N}\right]_{4}\left[\mathrm{~V}_{8} \mathrm{Cu}_{2} \mathrm{O}_{24}\right]$} & - & $\mathrm{H}_{2} \mathrm{O} / 70{ }^{\circ} \mathrm{C}$ & 4 & 88 & [35] \\
\hline 3 & $\mathrm{Cu}(\mathrm{II})-(\mathrm{C} 186 \text { tren })^{\mathrm{a}}$ & - & n-octane/r.t. & 24 & 84 & {$[36]$} \\
\hline 4 & $\mathrm{Cu}(\mathrm{II})-(\mathrm{MBHTM})^{\mathrm{b}}$ & $\begin{array}{l}\text { Sodium- } \\
\text { ascorbate }\end{array}$ & DMSO: $\mathrm{H}_{2} \mathrm{O} /$ r.t. & 4 & 94 & [37] \\
\hline 5 & $\mathrm{Cu}(\mathrm{II})-(\mathrm{BPPA})^{\mathrm{c}}$ & $\begin{array}{l}\text { Sodium- } \\
\text { ascorbate }\end{array}$ & $\mathrm{MeOH} / \mathrm{N}_{2} /$ r.t. & 16 & 99 & [38] \\
\hline 6 & $\mathrm{Cu}(\mathrm{II})-(\mathrm{Phox})^{\mathrm{d}}$ & - & $\mathrm{H}_{2} \mathrm{O} / 70{ }^{\circ} \mathrm{C}$ & 12 & 95 & [39] \\
\hline 7 & Complex 1 & $\begin{array}{c}- \\
\text { Sodium- } \\
\text { ascorbate }\end{array}$ & $\mathrm{H}_{2} \mathrm{O} / \mathrm{r}$.t. & 24 & 90 & $\begin{array}{l}\text { This } \\
\text { work }\end{array}$ \\
\hline
\end{tabular}

${ }^{\mathrm{a}} \mathrm{C} 186$ tren: Tris(2-dioctadecylaminoethyl)amine). ${ }^{\mathrm{b}}$ MBHTM: (1-(4-Methoxybenzyl)-1-H1,2,3-triazol-4-yl)methanol. $\quad{ }^{\mathrm{c}}$ BPPA: Bipyridinepyrazoleamine. ${ }^{\mathrm{d}} \mathrm{Phox}$ : 2-(2'hydroxyphenyl)-2-oxazoline 


\section{Conclusion}

The copper(II)-dipicolinate complex (1) was readily prepared in high yield via oxidation reaction of copper(I) iodide and the dipicolinic acid in water and acetonitrile as solvents in the presence of glycine. The copper (II) environment is built by a nitrogen and two carboxylateoxygens from a tridentate dipicolinate ligand plus two water molecules. The complex has been found to mediate azide-alkyne cycloaddition in effective and regioselective manners, leading to the formation of a variety of 1,4-disubstituted-1,2,3-triazoles. The present catalytic protocol is environmentally-benign because it is conducted in water as solvent and it proceeds either in presence or absence of reducing agents at room temperature.

\section{Supplementary material}

Supplementary material associated with this article, including NMR spectroscopic and high resolution mass spectrometry data and spectra, X-ray crystallographic data that confirm the structure of $\mathbf{1}$ is included.

\section{Acknowledgements}

We are grateful to the Spanish Ministerio Español de Ciencia e Innovación (Project CTQ2016-75068P), the Generalitat Valenciana (PROMETEO/2014/070), the Université Cadi Ayyad (UCAM) the Centre National de la Recherche Scientifique (CNRS) and the Brest University. 


\section{References}

[1] R. Huisgen. Angew. Chem. Int. Ed. Engl., 2, 565 (1963).

[2] R. Huisgen. Pure Appl. Chem., 61, 613 (1989).

[3] C. W. Tornøe, C. Christensen, M. Meldal. J. Org. Chem., 67, 3057 (2002).

[4] (a) V. V. Rostovtsev, L. G. Green, V. V. Fokin, K. B. Sharpless. Angew. Chem., Int. Ed., 41, 2596 (2002). (b) T. R. Chan, R. Hilgraf, K. B. Sharpless, V. V. Fokin. Org. Lett., 6, 2853 (2004).

[5] M. Meldal, C. W. Tornøe. Chem. Rev., 108, 2952 (2008).

[6] G. C. Tron, T. Pirali, R. A. Billington, P. L. Canonico, G. Sorba, A. A. Genazzani. Med. Res. Rev., 28, 278 (2008).

[7] M. S. Costa, N. Boechat, E. A. Rangel, F. D. Da Silva, A. M. T. de Souza, C. R. Rodrigues, H. C. Castro, I. N. Junior, M. C. S. Lourenco, S. Wardell, V. F. Ferreira. Bioorg. Med. Chem., 14, 8644 (2006).

[8] H. Nandivada, X. W. Jiang, J. Lahann. Adv. Mater., 19, 2197 (2007).

[9] Q. Deng, N-N. Ding, X-L. Wei, L. Cai, X-P. He, Y-T. Long, G-R. Chen, K. Chen. Corr. Sci., 64, 64 (2012).

[10] N.W. Smith, A. Alonso, C.M. BrownSergei V. Dzyuba. Biochem. Biophys. Res. Commun., 391, 1455 (2010).

[11] Y.H. Lau, P.J. Rutledge, M. Watkinson, M.H. Todd. Chem. Soc. Rev., 40, 2848 (2011).

[12] C. F. Ye, G. L. Gard, R. W. Winter, R. G. Syvret, B. Twamley, J. M. Shreeve. Org. Lett., 9, 3841 (2007).

[13] G-C. Kuang, H. A. Michaels, J. T. Simmons, R. J. Clark, L. J. Zhu. Org. Chem., 75, 6540 (2010).

[14] W. S. Brotherton, H. A. Michaels, J. T. Simmons, R. J. Clark, N. S. Dalal, L. Zhu. Org. Lett., 11, 4954 (2009). 
[15] M. Beller, C. Bolm. Transition Metals for Organic Synthesis, Wiley-VCH, Weinheim, (2004).

[16] B. Setlow, S. Atluri, R. Kitchel, K. Koziol-Dube, P. Setlow. J. Bacteriol., 188 (11), 3740 (2006).

[17] H. Ilkimen, C. Yenikaya, M. Sarı, M. Bulbul, E. Tunca, H. Dal. J. Enzyme Inhib. Med. Chem., 29(3), 353 (2014).

[18] M. C. Grossel, A. N. Dwyer, M. B. Hursthouse, J. B. Orton. CrystEngComm., 8, 123 (2006).

[19] H. Aghabozorg, F. Manteghi, S. Sheshmani, J. Iran. Chem. Soc., 5, 184 (2008).

[20] N. Okabe, N. Oya, Acta Cryst., C56, 305 (2000).

[21] M. Mirzaei, H. Eshtiagh-Hosseini, M. Bazargan, F. Mehrzad, M. Shahbazi, J. T. Mague , A. Bauzá , A. Frontera, Inorg. Chim., Acta 438, 135 (2015).

[22] S. K. Ghosh, J. Ribas, P. K. Bharadwaj. CrystEngComm., 6, 250 (2004).

[23] H. L. Gao, L. Yi , B. Zhao, X. Q. Zhao, P. Cheng, D. Z. Liao, S. P. Yan. Inorg Chem., 45, 5980 (2006).

[24] N. Büyükkıdan, C. Yenikaya, H. İlkimen, C. Karahan, C. Darcan, T. Korkmaz, Y. Süzen. J. Mol. Struct., 1101, 139 (2015).

[25] A. T. Çolak, F. Çolak, O. Z. Yeşilel, O. Büyükgüngör. J. Coord. Chem., 62, 1650 (2009).

[26] Complex 1 was already structurally elucidated by X-ray crystallography in both Triclinic and Monoclinic, see: M. Koman, J. Moncol, D. Hudecova, B. Dudova, M. Melnik, M. Korabik, J. Mrozinski, Pol. J. Chem. 75, 9572001.

[27] G. M. Sheldrick, Acta Cryst., A64, 112 (2008).

[28] S. Tamilmani, W. Huang, S. Raghavan, and R. Small, J. Electrochemical Soc., 149, G638 (2002). 
[29] Q. Zang, G. Q. Zhong, M-L. Wang. Polyhedron, 100, 223 (2015).

[30] K. Nakamoto, Infrared and Raman Spectra of Inorganic and Coordination Compounds, Part B, John Wiley \& Sons Inc., New York, (2009).

[31] K. Helios, R. Wysokinski, A. Pietraszko, D. Michalska. Vibrational Spect., 55, 207 (2011).

[32] A. Addison, T. N. Rao, J. Reedijk, J. van Rijn and G. C. Verschoor, J. Chem. Soc., Dalton Trans., 1349 (1984).

[33] G. C. Kuang, P. M. Guha, W. S. Brotherton, J. T. Simmons, L. A. Stankee, B. T. Nguyen, R. J. Clark, L. Zhu. J. Am. Chem. Soc., 133, 13984 (2011).

[34] K.R. Reddy, K. Rajgopal, M.L. Kantam. Synlett., 6, 957 (2006).

[35] M. Amini, S. B. Tekantappeh, B. Eftekhari-Sis, P. G. Derakhshandeh, K. V. Hecke. J. Coord. Chem., 70, 1564 (2017).

[36] L. Harmand, M. H. Lescure, N. Candelon, M. Duttine, D. Lastécouères, J. M. Vincent. Tetrahedron Lett., 53, 1417 (2012).

[37] R. H. Tale, V. B. Gopula, G. K. Toradmal. Tetrahedron Lett., 56, 5864 (2015).

[38] B. Han, X. Xiao, L. Wang, W. Ye, X. Liu. Chin. J. Catal., 37, 1446 (2016).

[39] M. Bagherzadeh, A. Bayrami, R. Kia, M. Amini, L. J. Kershaw Cook, P. R. Raithby. Inorg. Chim. Acta, 466, 398 (2017). 